\title{
Comparative Theories and Methods: Between Uniplexity and Multiplexity
}

Recep Şentürk v.dğr.

İstanbul: Ibn Haldun University Press, 2020, 456 sayfa

ISBN 9786050690576

Prof.Dr. Recep Şentürk başkanlığında bir heyet tarafindan hazırlanan Comparative Theories and Methods adlı kitap sosyal ve beșeri bilimler okuyan öğrencilere alanlarındaki çeşitli teorilerin ve metotların sistematik bir incelemesini sunmanın yanında alternatif bir teorik yaklaşım önermeyi de hedefleyen bir giriş kitabıdır. Kitabın alt başlığ 1 olan Between Uniplexity and Multiplexity ifadesi eserde yer alan teorilerin ve metotların incelendiği çerçeveye işaret etmektedir. "Uniplexity” ve "multiplexity" kavramları sırasıyla "tek katmanlı/düzeyli” ve "çok katmanlı/düzeyli” olarak çevrilebilir. Katmandan veya düzeyden kastedilen, teorilerin ve metotların gerçekliği tek veya birden fazla farklı seviyede anlamlandıran, yorumlayan, açıklayan ve işleyen bir yapıda olmalarıdır. Multiplexity kavramı İslamî ilimler literatüründeki "merâtip" kavramını karşılayan bir terim olarak kullanılmıştır. Uniplexity ve multiplexity kavramları kitapta anlatılan bütün teoriler ve metotlar için bir tasnif kriteridir ve kitabın temel iddiası bu kavramlar etrafında şekillenmektedir.

Yazarlar sosyal ve beşeri bilimler alanında yaygın kabul gören teorilerin ve metotların gerçekliği anlama ve açıklamada yetersiz olduğunu, alternatif ve daha yetkin bir teorik yaklaşımın mevcut olduğunu iddia etmektedir. Eleştirinin hedefi Batı menşeli sosyal teoriler ve metotlardır. Bu yaklaşımların, içinde neşet ettikleri toplumun ve zamanın zihnî yapısının ve dünya tasavvurunun sonucu olarak doğdukları, dolayısıyla belli ontolojik, epistemolojik ve metodolojik kabuller barındırdıkları tespit edilmektedir. Bu kabuller tek katmanlı bir gerçeklik anlayışına yaslanır ve bu gerçekliğe kısıtlı bir çerçevede ulaşma imkânı sunar. Her ne kadar ana akım sosyal ve beşeri bilimler ekolojisinde temel yaklaşımlara karşı gelişen eleştirel teoriler ve metotlar olsa da bunlar da benzer eksikliklerle maluldür.

Sosyal ve beşeri bilimlerin doğduğu ve geliştiği coğrafyanın ve dönemin dışından alternatif bir yaklaşım geliştirilebilir. Bu yaklaşım temelde çok katmanlı yaklaşımdır. Çok katmanlı yaklaşım Batı dışındaki coğrafyalarda (bazı örneklerde Batıda da) kullanılagelen birçok teoriyi ve metodu tanımlayan bir ifadedir. Kitapta, ilmî anlamda daha olgunlaşmış bir çerçeve sundukları 
için İslam medeniyetinden örnekler üzerinde durulduğu ifade edilmekle beraber farklı medeniyetlerin değişik zamanlarda çok katmanlı ilmî yaklaşımlar geliştirdiğinin altı çizilmiştir. Çok katmanlı yaklaşımın tek katmanlıdan temel farkı, gerçekliği farklı ontolojik düzeylerden oluşan bütüncül bir çerçevede ele almasıdır. Farklı varlık mertebeleri (merâtibü’l-vücĥd) olduğu halde bunlar birbirinden kopuk değildir. Aynı şekilde çok katmanlı epistemoloji (merâtibüll-ilm) varlı̆̆ın farklı veçhelerine dair doğru bilgi edinmenin yollarını ortaya koyar. Nihayetinde her varlık düzeyine yönelik bilgi edinme çok katmanlı bir metodolojinin (merâtibü'l-usûl) imkânları ile gerçekleşir. Çok katmanlı teoriler ve metotlar gerçekliği anlama ve anlamlandırmada daha geniş bir perspektiften bakma ve varlığın farklı düzeylerini ihata edebilme imkânı sunduğu için tek katmanlı yaklaşımlara göre tercih edilmeleri gerekir.

Eser üniversite eğitimi için giriş düzeyinde bir ders kitabı olarak tasarlanmıştır. İbn Haldun Üniversitesi bünyesindeki öğretim üyesi ve asistanlardan oluşan bir ekip tarafından hazırlanan "Comparative Theories and Methods" dersinin materyalleri, dökümü yapılan ders kayıtları ve öğrenci geri bildirimleri kitabın temelini oluşturmaktadır. Dersi yürüten ekibin ortak çabası sonucu ortaya çıkan kitap, ders materyali olarak kullanılmış, dolayısıyla uygulaması yapılmış bir eser olmanın getirdiği bütüncül ve oturmuş bir yapıya sahiptir. Bir ders kitabı olarak incelendiğinde kitabın içeriği, bu içeriğin tasnifi, görsel dizaynı ve öğrenci dostu bir yapıda olması gibi hususlarda Türkiye'de pek sık rastlamadığımız bir yeterlilikte olduğu söylenebilir.

Bir dersin meyvesi olması sebebiyle kitap bir dönemlik üniversite dersi planı ile örtüşecek şekilde düzenlenmiştir. On üç bölüm ihtiva eden kitap, bölümlerin konu bazlı gruplandırılmasıyla meydana getirilen altı modülden oluşmaktadır. Teorilerin ve metotların oluşum süreçlerini anlamaya yönelik bir giriş mahiyetindeki birinci modül ontoloji, epistemoloji ve metodoloji konularında birer bölüm olmak üzere toplam üç bölümden oluşmaktadır. İkinci modül toplumsal bilimlerin (societal sciences) tarihsel gelişimi ve araştırmalarda kullanılacak analiz düzeyleri meseleleri etrafında birer bölüm ihtiva etmektedir. Üçüncü, dördüncü ve beşinci modüller Batılı sosyal ve beşeri bilimler geleneğinde kabul görmüş temel yaklaşımları kendi içlerindeki eleştirel ilişkilerini de dikkate alarak inceleyen bölümlerden oluşmaktadır. Son modül ise çok katmanlı yaklaşıma uygulamalı bir örnek olarak İbn Haldun'un teorisi, metodolojisi, Osmanlı ve günümüzdeki etkisine odaklanmaktadır.

İlk modülde tek katmanlı ontoloji, epistemoloji ve metodoloji konuları materyalizm (pozitivizm) ve idealizm ikiliği çerçevesinde oluşan teorik 
yaklaşımlarla örneklendirilmiştir. Çok katmanlı yaklaşım ise varlık, bilgi ve usulü farklı mertebelerle tasnif eden İslamî ilimler geleneğine başvurularak anlatılmıştır. Taşköprizâde, Gazzâlî ve Erzurumlu İbrahim Hakkı gibi farklı isimlerden alıntılarla "merâtip" yaklaşımı açıklanmıştır. İkinci modülde ise "toplumsal bilim" kavramı (societal science-kitapta ifade edildiğine göre ilk olarak Recep Şentürk tarafından İslam Dünyasında Modernleşme ve Toplumbilim adlı eserde ortaya konan bir kavramdır) çerçevesinde topluma dair bilimsel bilgi üretiminin farklı medeniyetlerde nasıl geliştiği ve elde edilen bilgi birikiminin mesele edindiği olguları farklı analiz düzeylerinde nasıl incelediği anlatılmıştır. Özellikle sosyal bilimler ve fıkhın açıklayıcılık ve normatiflik çerçevesinde karşılaştırıldığı kısım ilgi çekicidir.

Sonraki üç modül Batılı sosyal ve beşeri bilimlerden örneklerle pozitivist ve idealist yaklaşımların incelenmesini içermektedir. Bu kısımda pozitivizm, pozitivizme içeriden getirilen eleştiriler, Marksizm, feminizm, eleştirel teori, postkolonyal çalışmalar, sosyal inşacılık ve hermenötik gibi farklı teorik yaklaşımlar ve bu yaklaşımları temsil eden isimlerden bahsedilmektedir. Batı dünyasında sosyal ve beşeri bilimlerin nasıl bir birikim arzettiğini anlaşılır kılacak örnekler çok ayrıntıya girmeden aktarılmıştır. Kitabın sonraki kıs$\mathrm{m}$ ise İbn Haldun ve ortaya koyduğu teorik yaklaşıma odaklanmıştır. İbn Haldun'un teorik yaklaşımı hem çok katmanlı yaklaşıma bir örnek olarak incelenmiş hem de Osmanlı özelinde nasıl bir etkiye sahip olduğu tartışılarak bu yaklaşımın ilim dünyası için önemine işaret edilmeye çalışılmıştır. Son kısımda çok katmanlı yaklaşımın Batı menşeli tek katmanlı yaklaşımların sınırlandırdığı düşünce dünyamızda gerçekliği anlama ve yorumlama noktasında açılım sağlayabilecek bir alternatif sunduğu vurgulanarak kitabın devamı olacak bir ciltte çok katmanlı yaklaşımların daha ayrıntılı anlatılacağı ifade edilmiştir. Kitabın en sonunda İbn Haldun'un hayatı, yaşadığı yerlerin bir haritası üzerinden kronolojik olarak gösterilmiştir.

Eser şekil açısından değerlendirildiğinde genel olarak başarılıdır. Özellikle sayfa tasarımı, takibi kolaylaştırıcı bol tablo kullanımı, kısa bilgi kutuları, literatürden yapılan isabetli alıntılar, bölüm sonlarında yer alan sözlük ve ileri okuma önerileri gibi unsurlar giriş seviyesindeki öğrenciler için kitaptan daha çok verim alma imkânı oluşturmaktadır. Metinde bazı dizgi hatalarına rastlansa da, bunlar rahatsızlık verecek seviyede değildir. Bununla birlikte başlıklar arasındaki düzey farkının takip edilmesini zorlaştıran, meselelerin değişimine bağlı olarak genelde aynı düzeyde devam eden bir başlıklandırma usulü tercih edilmiştir. Teorilerin ve metotların incelendiği bölümlerde konuların akışını izlemeyi zorlaştıran bu durum, anlatılan konuların bir diğerinin alt başlığı olduğu bazı noktalarda muğlaklığa sebep olmuştur. 
İçerik açısından incelendiğinde ise eser bir giriş kitabı olarak çoğunlukla yeterli olmakla birlikte bazı hususlarda geliştirilmeye ihtiyaç duyduğu söylenebilir. Kitabın tek katmanlı ve çok katmanlı ikili tasnifi çerçevesinde ortaya koyduğu iddiayı temellendirme noktasında teorik yaklaşım açısından yeterli bir malzeme sunulmaktadır. Ancak çok katmanlı teorilere ve metotlara dair daha çok örnek verilmesi okuyucular açısından faydalı olacaktır. Kitabın takip eden cildinde bu örneklerin çeşitlendirileceği vaat edilmiştir. Kitapta da ifade edildiği gibi bazı durumlarda genellemeler yapılarak ele alınan teori ve metodolojilere dair nüanslara yer verilmemiştir, fakat bu durum eserin meramını aktarmasına mani olmamış veya yanıltıcı bir tavra yol açmamıştır. Diğer yandan bir giriş kitabı olması açısından sosyal ve beşeri bilimler alanlarında yer alan giriş kitapları ile karşılaştırıldığında tek bir disipline hasredilmiş olmaması sebebiyle bu kitaplara göre daha az ayrıntıya girilmiştir. Dolayısıyla siyaset veya sosyoloji gibi bir alanda yazılan bir giriş kitabının kendi alanına dair zenginliğinden mahrumdur. Kitap karşılaştırmalı bir teorik yaklaşım inşa etmeyi hedeflediği ve mevcut teorileri aşan yeni bir yaklaşım sunmayı arzuladığı için bu durumun eserin gayesi ile çelişmediğini söyleyebiliriz.

Kitabın içeriği ile ilintili olarak dikkat edilmesi gereken diğer bir husus muhatabına uygunluğudur. Giriş seviyesinde bir lisans dersi için sunulan bilgi ve sunum şeklinin yeterli olduğu rahatllkla söylenebilir. Kitapta öğrencilerin tartışlan meselelerdeki temel noktalara vâkıf olabileceği bir üslup kullanılmış, onları daha ileri araştırma yapmak istediklerinde yönlendirebilecek ek bilgiler sunulmuş ve sosyal veya beșeri bilimler yolculuğunun başındaki bir öğrencinin algılayabileceği bir dil kullanılmıştır. Bununla beraber tartışılan teorilerin ve metotların çok ayrıntılı anlatılmaması giriş seviyesindeki öğrenciler için zorlayıcı olabilir. Bu sebeple kitap, sosyal ve beşeri bilimler alanına dair belli bir bilgi birikimine sahip okuyucular için daha anlaşılır bir yapıya sahiptir.

Kitabı, fikrî bağımsızlığ sağlamaya yönelik bir çalışma olarak alternatif bir teorik ve metodolojik yaklaşım sunma iddiası bağlamında ele aldığımızda ise temel kurgusu açısından başarılı olsa da giriş seviyesinde bir çalışma olmanın getirdiği sınırlılıklar ile karşılaşmaktayız. Eserin kurgusu ilk olarak genel teorik çerçeveyi vazetme, sonrasında örnekler üzerinden bu teorik yaklaşımın açımlanması şeklindedir. Meseleler genelde en basit sorudan başlanarak anlatılmıştır. Bu açıdan öğrencinin takip ederken konunun genişliği karşısında boğulmayacağı bir anlatı mevcuttur. Bununla birlikte tartışılan meselelerin kaçınılmaz derinliği zaman zaman okuyucunun konuyu takipte zorlanmasına sebep olarak meseleleri tam olarak kavramasını zorlaştıracak 
bir görünüm arzetmektedir. Hususan çok katmanlı ontoloji, epistemoloji ve metodolojinin anlatıldığı kısımlarda birçok sosyal ve beşeri bilim öğrencisinin aşina olmadığı bir terminoloji ve literatüre sık atıflar olmakla birlikte bu atıflar bazan aralarındaki irtibat tam kurulmadan bazan da yeterince açılayıcı bir şekilde ifade edilmeden yapılmaktadır. Mesela epistemolojiye hasredilen bölümde çok katmanlı epistemoloji için İslamî ilimler literatüründen bilgi ve bilgi edinme yollarına dair pek çok farklı tasnif sıralanmaktadır. Fakat bu tasniflerin nasıl aynı anda değerlendirileceği, aralarında nasıl bir ilişki olduğu, toplamda nasıl bir bütüncül tasavvur sundukları giriş seviyesindeki bir okuyucunun anlayacağı sarihlikte açıklanmamıştır. Bu durum giriş kitabı olmanın getirdiği sınırlılıklardan kaynaklanıyor olabilirse de bazı konularda daha net bir şekilde yapılandırılmış bir anlatı sunmak muhatap açısından faydalı olacaktır. Giriş seviyesinde okuyuculara hitap edildiği düşünüldügünde, genel olarak çok katmanlı yaklaşımların daha ayrıntılı örneklendirilmesine meselelerin anlaşılması açısından ihtiyaç duyulmaktadır.

Kitapta temel bir yere sahip toplumsal bilim kavramsallaştırması da beraberinde bazı sorular getirmektedir. Bu kavram her toplumun kendi tarihsel ve ilmî tecrübesi çerçevesinde ortaya koyduğu, toplumu anlama ve düzenleme gayesine sahip bilimsel birikimine işaret etmektedir. Buna göre Batı toplumunun tecrübesi sonucu sosyal bilimler, İslam medeniyetinde ise benzer şekilde fıkıh ilmi ortaya çıkmıştır. Bu şekilde bakıldığında sosyal bilimler ve fıkıh aynı düzlemde karşılaştırılan ve değerlendirilen iki ilmî çaba olmaktadır. Fakat bunların açıklayıcılık ve normatiflik açısından aynı fonksiyona sahip ilimler olduğu iddiası yeterince detaylandırılarak savunulmamıştır. Diğer yandan evrensel bir toplumsal bilim olmadığ 1 ve her toplumun kendi hususiyetlerini taşıyan ilmî gelenekler ürettiği iddiası farklı bilimsel yaklaşımların birbiriyle nasıl etkileşime gireceği sorusunu da cevapsız bırakmaktadır. Sosyal bilimlerin İslam toplumu için bir şey ifade edip etmediği veya fikhın müslüman olmayan toplumlara söyleyebilecek bir şeyi olup olmadığ laktır. Bilimsel yaklaşımların bu derece keskin bir şekilde toplumların tarihsel tecrübesine bağlı olarak tasvir edilmesi ve diğer toplumlar için geçerli olmadığının altının çizilmesiyle beraber insanın yaşadığı tarihsel dönem veya coğrafyadan bağımsız olarak taşıdığı evrensel hususiyetlerin mevcudiyeti tartışılmamıştır. Bu meselenin de giriş seviyesindeki okuyucular için anlaşılmasının zor olduğu âşikârdır. Kitabın sonunda vaat edilen II. cildin bu hususta daha aydınlatıcı bir tartışma içereceği umulmaktadır.

Comparative Theories and Methods adlı kitabın içeriği, üslubu ve iddiası dikkate alındığında ülkemizde yayımlanan ders kitapları için çıtayı yükseğe taşıdığı görülmektedir. Sosyal ve beşeri bilimler öğrencilerinin ihtiyaç 
duyacakları temel teorik ve metodolojik bilgiler, disipliner sınırlılıklar içerisinde kalınmadan, özgün ilmî araştırma yapmak için temel gereksinimlerden olan eleştirel bakışı kazandıracak bir çerçevede sunulmaktadır. Özellikle akademik literatürde hâkim olan Avrupa merkezci yaklaşımın olduğu gibi aktarılmayıp özgün ilmî birikimimize dikkat çekilmesi, eserin eğitim dünyası için önemini arttırmaktadır. Eserin alametifarikası olan tek ve çok katmanlı ayırımı üzerinden ortaya konan yaklaşım akademik camiada faydalı tartışmalar doğurma potansiyeline sahiptir.

Abdullah Said Arı, Arş.Gör. İstanbul Medeniyet Üniversitesi Siyasal Bilgiler Fakültesi ORCID 0000-0003-4496-8008 DOI $10.26570 /$ isad. 957322 